ZOOLOGIA 28 (3): 297-304, June, 2011

doi: $10.1590 /$ S1984-46702011000300003

\title{
Age and growth of Cetengraulis edentulus (Clupeiformes: Engraulidae) in a subtropical bight of Southern Coast Brazil
}

\author{
José Maria Souza-Conceição' \& Paulo Ricardo Schwingel ${ }^{2}$
}

\author{
${ }^{1}$ Universidade da Região de Joinville. Rua Paulo Malschitzki 10, Campus Universitário, Zona Industrial, 89219-710 Joinville, \\ SC, Brazil.E-mail: zzze.maria@yahoo.com.br \\ 2 Centro de Ciências Tecnológicas da Terra e do Mar, Universidade do Vale do Itajaí. Rua Uruguai 458, Caixa Postal 360, \\ 88302-202 Itajaí, SC, Brazil. E-mail: schwingel@univali.br
}

\begin{abstract}
Age and growth of Cetengraulis edentulus (Cuvier, 1828) in the Saco dos Limões bight (Southern Brazil) were studied. Sampling was carried out from August 2001 to July 2003. The study of age and growth was based on the interpretation of the periodicity of ring formation in the otoliths sagittae of 491 individuals, temporal variation of otolith edge, relative marginal increments (RMI), age-length key, and von Bertalanffy curve. Cetengraulis edentulus otoliths were adequate for the interpretation of age with $86 \%$ of legibility, in which a translucent zone and its adjacent opaque zone were deposited each year. The translucent zone is formed during the cold period and the opaque zone in the warm period. Fish aged 0 (<12 months) -4.0 year old were found and the population structure reveals the predominance of individuals 1.0 and 2.0 year old. The species has a fast growth, and the growth equation is $L_{t}=156.70\left(1-e^{-1.05(t-0.002)}\right)$. Cetengraulis edentulus attains the sexual maturity with 1.19 year for the females and 1.12 year for the males, which occur in all life stages throughout the year in the study area.
\end{abstract}

KEY WORDS. Anchovy; life cycle; maturity; otolith.

Estuarine areas are important sites for breeding (VIEIRA \& Scalabrin 1991, García-Abad et al. 1998, Elliott \& Hemingway 2002, Araújo et al. 2002a) and growth of many species of fishes (Boehlert \& Mundy 1988, Moyle \& Cech Jr. 1996, Rozas \& Minello 1997, VannucCi 1998, Costello et al. 2002, FalCÃo et al. 2006). The high productivity associated with shallow waters makes many favorable habitats available. Estuarine areas support diverse fish species in various stages of their life cycles (YANESArancibia 1986). In general, members of the family Engraulidae are important components of the fish community in these ecosystems (Figueredo \& Menezes 1978, Whitehead 1988).

Cetengraulis spp. (Clupeiformes: Engraulidae) occurs in Central and South America, in the Atlantic and Pacific oceans, up to extreme southern North America (WhiteheAd 1988). The western Atlantic in the Caribbean region had a connection with the Pacific Ocean until the Pleistocene (Lowe-McConnell 1999), and the complete closure between the two oceans by the Isthmus of Panama appears to be directly related to the division of the genus into two species (Nelson 1984). These species, Cetengraulis edentulus (Cuvier, 1828) and Cetengraulis mysticetus (Günther, 1867), occur from the Caribbean to southern Brazil, and from the Gulf of California to Peru, respectively (WhiteHEAD 1988). Cetengraulis mysticetus is better studied, particularly in Colombia, where it has been increasingly exploited (Maldonado \& Remolina 1978). Efforts to acquire information leading to a sustainable exploitation of C. mysticetus were done, however, started late, and production in that area has fallen to a third (WhiteHeAD 1988). The engraulid C. edentulus occurs from Panama to the northern coast of the state of Santa Catarina, southern Brazil $-23^{\circ} \mathrm{N}-28^{\circ} \mathrm{S}, 85^{\circ} \mathrm{W}-32^{\circ} \mathrm{W}$ - (Figueredo \& Menezes 1978, WHITEHEAD 1988), being a common and abundant inhabitant of estuaries. For instance, $43 \%$ of the fish identified at the Itaipu Lagoon (Rio de Janeiro, Brazil) after a one-year collection cycle, belonged to the family Engraulidae, and were mostly represented by C. edentulus (SERgIPEnSE \& Pinto 1995). The species is also well represented in the fish fauna of the Sepetiba Bay, Rio de Janeiro (Pessanha et al. 2003, Sergipense et al. 1999). Additionally, of the 79 fish species found by DA-GraçA-Lopes et al. (1993) in the fish community of Santos Bay (São Paulo, Brazil), C. edentulus was one of the most abundant. In Santa Catarina, the species attracts commercial attention because of its abundance and frequency in bights, bays and lagoons. Catch records from only one commercial fishing company in the state reached 250 tons of C. edentulus per month in a summer (A. I. DA-CosTA, pers. comm.), the peak catch season. However, the total fishery potential of the species is not known. In Jurerê (on the northwest coast of Florianópolis, Brazil), C. edentulus is very abundant in traditional fishery catches, particularly in summer (information obtained locally). At the Itacorubí mangrove in Baía Norte,Florianópolis, monthly sampling with nylon casting nets caught significant quantities of C. edentulus year-round (Clezar et al. 1993). 
Cetengraulis edentulus occurs widely in the study area and can be commercially exploited; nevertheless, studies are needed to devise a fishery management plan for the species. When studying the biology of a species, is essential to gather knowledge on its reproductive aspects, because they indicate the seasons and areas of maximum abundance in response to important stimuli such as spawning. Information on sexual maturation is important to establish a standardization index and to avoid overfishing, which may cause a decrease in the biomass of the population (GALLONieTo 1993b). SouZA-ConCeIÇão et al. (2005) described the length at first maturation for females and males of C. edentulus; however, they did not include a study on growth and age, but suggested that these parameters are important and should be investigated.

Although data exist on the reproduction of $C$. edentulus (SouzA-Conceição et al. 2005), the age at maturity is still not known. The biology of C. edentulus is probably very similar to that of C. mysticetus in the eastern Pacific (Whitehead 1988). The latter reaches its first maturity after one year, at about 125 mm (Howard \& Landa 1958). However, a study on age and growth of C. edentulus is necessary (SouzA-ConCEIção et al. 2005). The species is presently attracting interest on the coast of Santa Catarina as a potentially exploitable biological resource, but scientific information is lacking to support a sustainable management of C. edentulus. The principal objective of this paper was to study the age and growth of $C$. edentulus in a subtropical environment, making reference parameters available for the management and conservation of this species.

\section{MATERIAL AND METHODS}

The present study was carried out at Saco dos Limões (Fig. 1), a bight with estuarine characteristics situated in the west coast of the Santa Catarina Island, municipality of Florianópolis (southern Brazil). The bight is shallow (2-8 $\mathrm{m}$ ), has sandy-muddy bottom with large amounts of biodetritic material, and is surrounded almost completely by mangrove forests, salt marshes and urbanized areas. In the bight and adjacent area, water column dynamics is strongly linked to the continental drainage - main river: Tavares (SCHETTINI et al. 2000, SouZA-ConCeIÇão et al. 2005) , the rain season, and the sea influence.

Biological material was obtained by surveys carried out from August 2001 to July 2003 at six stations (Fig. 1). The samples were collected using a double rig trawl. Each net had two wooden doors, a total length of $7.5 \mathrm{~m}$, a float line of $7 \mathrm{~m}$ and a lead line of $8.0 \mathrm{~m}$. The mesh used was $12 \mathrm{~mm}$ knot-toknot, and the fishing effort was standardized at 10 minutes.

In the laboratory, the total length (precision $0.1 \mathrm{~mm}$ ) of all individuals caught was measured. For the biological analyses, subsamples of at least 30 specimens were taken, and the right and left sagittal otoliths of each fish were removed and stored. The otoliths were sampled in bimonthly collections from August 2001 to August 2002. However, to provide a precise analysis of the formation of annual rings, beginning in August

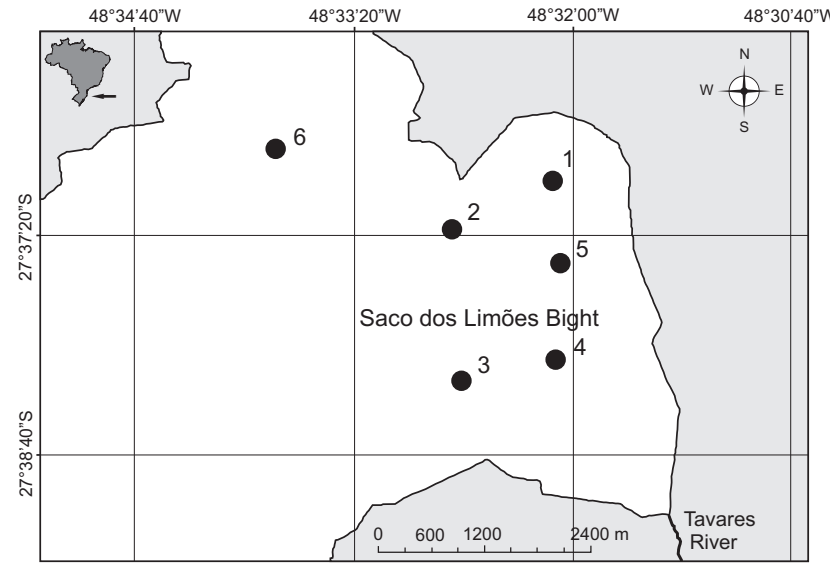

Figure 1. Study area and localization of sampling stations at Saco dos Limões bight, southern Brazil.

2002 and continuing through July 2003, fish were collected monthly for extraction of the otoliths.

For age determination, the otoliths were observed whole by means of a binocular stereoscopic microscope, connected to an Image-Pro ${ }^{\circledR}$ Plus Version 3.0 image analysis system. The images were digitalized and the annual rings were observed. The experiments on otolith observation resulted in the standardization of a reading method, which used a magnification of $15 x$, immersion of the structure in $70 \%$ ethanol, incident light, and dark-field contrast. The concave side of the right otolith afforded the best observation of the rings and edges. The preferred reading region was the upper posterior part, as confirmed by observations of the complete structure. The opaque central area was defined as being the initial life stage of the specimens, appearing after a translucent band followed by an opaque one, and successively with increase of size (Fig. 2). After the method was standardized, three readings per fish were done, at intervals of at least 20 days.

The counts excluded the larval ring, which was generally represented by opaque central area without any band definition. After the larval ring, the count began with the first translucent band; complete rings show one translucent band and one completely formed opaque band, that is, with a new translucent band appearing at the edge. Individuals with only one band were considered to be in the first year of life (the age class 0: individuals less than one year of age; $<12$ months).

Data that showed variability or error among the three readings were discarded. The data were compared by calculating the Coefficient of Variation (CV) and the Average Percentage Error (APE) according to CAMPANA (2001), which measure the variability and the percentage errors of the readings in relation to the mean counts of the rings of each otolith.

The relationship between the length (in millimeters) of the otoliths and the length of the fish was determined and graphed. The measurements were always taken along the long- 




Figure 2. Characteristics of whole sagittal otoliths of C. edentulus captured in the Saco dos Limões bight (southern Brazil). Central circle: opaque central area, black circles: translucent marks, and white circles: opaque marks. Scale bar: $1 \mathrm{~mm}$.

est axis of the otolith. The validation process was based on an analysis of temporal variation of the edge type (CLAY \& CLAY 1991, Campana \& Jones 1992, Martins \& Haimovici 2000, Campana 2001), in percentages of the opaque and translucent edges of otoliths from 571 fish during the study period. As a second method, the evolution of the relative marginal increment - RMI (precision $0.01 \mathrm{~mm}$ ) was analyzed. Marginal increments were calculated using the equation proposed by CALDWALLADER (1978). The objective of this stage of the study was to identify the existence of a deposition pattern between opaque and translucent bands at the edge of the accretion structure, thus determining the number of rings formed annually. To assess the existence of differences between months in the mean marginal increment, the KruskalWallis test was used. If a difference was found, Dunn's a posteriori test was applied to make multiple comparisons among months.

To estimate the von Bertalanffy growth parameters (vON Bertalanffy 1938, Beverton \& Holt 1957, Kimura 1980), i.e. L $_{\infty}$ $\mathrm{k}$, and $\mathrm{t}_{0}$, the iterative method was used, which estimates the three parameters simultaneously by means of the "solver" tool of Microsoft Excel 7.0. This tool alters the value of each parameter and finds the smallest values for the sum of the squares of the residual, i.e., the square of the distance between the observed lengths and the lengths estimated from the growth model. The observed lengths of all the individuals in each age class were then applied to adjust the von Bertalanffy growth curve for the length of the species for a particular age (BEVERTON \& Holt 1957, Guland 1988, Hilborn \& Walters 1992, King 1996, Sparre \& Venema 1997). When the age of the individuals was calculated, the age/length key was constructed, which allows the individuals to be divided into age classes (SPARRE $\&$ Venema 1997). The von Bertalanffy model described by the following equation: $\mathrm{L}_{\mathrm{t}}=\mathrm{L}_{\infty}\left(1-\mathrm{e}^{\mathrm{k}(\mathrm{t}-\mathrm{t})}\right)$, where: $\mathrm{L}_{\mathrm{t}}=$ length at age $\mathrm{t}$; $\mathrm{L}_{\infty}=$ the asymptotic length; $\mathrm{k}=$ the growth coefficient; $\mathrm{t}=$ age; $\mathrm{t}_{0}=\mathrm{is}$ the hypothetical age at which length is equal to zero.
The age at maturity was estimated from the results for the size at first maturation of the species in the study area, as well as the information on spawning period (SouZA-ConCEIÇão et al. 2005). The length was converted to age by rearranging the von Bertalanffy equation (Beverton \& Holt 1957, Gulland 1988, 1989, Hilborn \& Walters 1992, King 1996, Sparre \& Venema 1997) and using the estimated growth parameters.

\section{RESULTS}

The relationship between the size of the otoliths and the size of the fish was positive and linear, giving the equation $\mathrm{L}_{\mathrm{t}}=$ $27.58 \mathrm{~L}_{\mathrm{ot}}-2.016$ (Fig. 3). This relationship presented the value of 0.746 for the coefficient of determination $\left(\mathrm{r}^{2}\right)$.

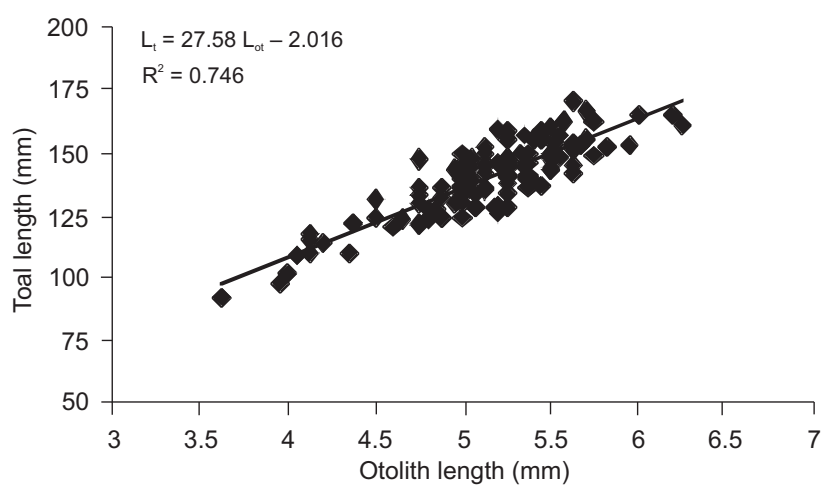

Figure 3. Relationship between the otolith size $(\mathrm{mm})$ and total length $(\mathrm{mm})$ of $C$. edentulus individuals from Saco dos Limões bight (southern Brazil).

The record of relative marginal increment (Fig. 4) indicated two distinct periods during the year, one with a larger and the other with a smaller increment. The Kruskal-Wallis test indicated the existence of significant differences between the months, and the a posteriori Dunn's test assigned the significant differences $(\mathrm{p}<0.05)$ to the periods between winter/ spring and summer/fall months (Tab. I). In the analysis of the percentage dominance of the edges, between August 2001 and July 2003, only one annual peak was observed for each type of edge. The translucent zone is formed during the cold period and the opaque zone in the warm period (Fig. 5). The species reproduces more intensely between October and February in the study area, and a clear pattern of greater frequency of translucent bands on the edge of the otoliths was observed in October 2001 and the period from August 2002 to November 2002 (Fig. 5). This pattern coincided with the period of greater marginal increments (Fig. 4), evidencing the period of ring formation. The combination of these results allowed the age to be validated, indicating the formation of one ring (one translucent and one opaque mark) per year. 


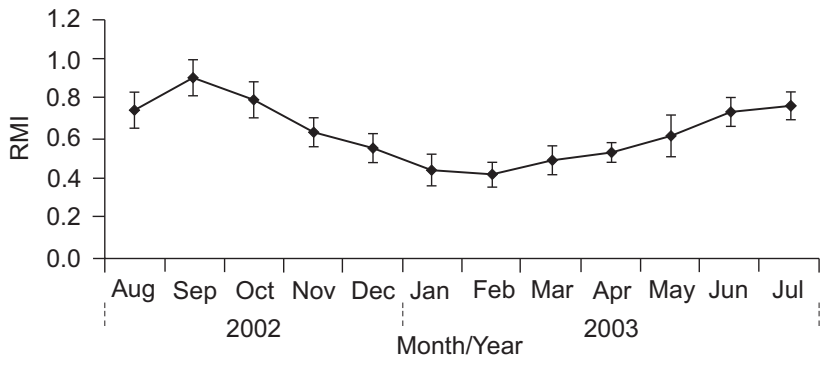

Figure 4. Monthly average (mean \pm standard error; SE) of relative marginal increment (RMI) in otoliths of $C$. edentulus in the Saco dos Limões bight (southern Brazil).

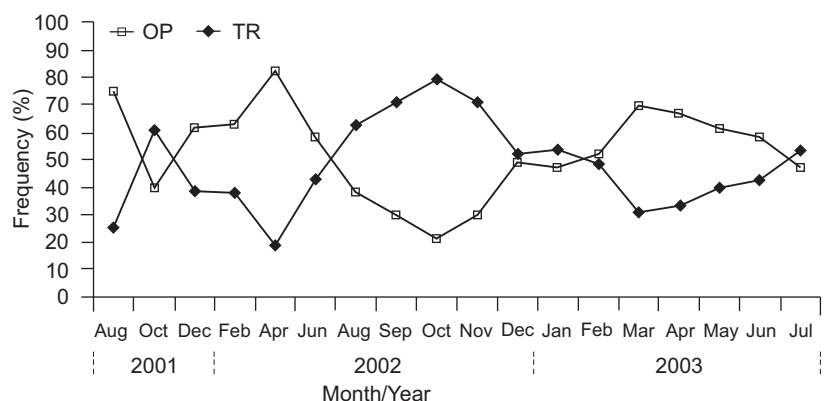

Figure 5. Monthly frequency (\%) of opaque (OP) and translucent (TR) edges in otoliths of $C$. edentulus in the Saco dos Limões bight (southern Brazil).

Table I. Results of Dunn's test for the monthly values of the relative marginal increment (RMI) for C. edentulus in the Saco dos Limões bight (southern Brazil).

\begin{tabular}{lc}
\hline \multicolumn{1}{c}{ Comparison } & $\mathrm{p}$ Value \\
\hline August $\times$ February & $\mathrm{p}<0.050$ \\
September $\times$ December & $\mathrm{p}<0.050$ \\
September $\times$ January & $\mathrm{p}<0.001$ \\
September $\times$ February & $\mathrm{p}<0.001$ \\
September $\times$ March & $\mathrm{p}<0.050$ \\
September $\times$ April & $\mathrm{p}<0.050$ \\
October $\times$ January & $\mathrm{p}<0.050$ \\
October $\times$ February & $\mathrm{p}<0.050$ \\
October $\times$ March & $\mathrm{p}<0.050$ \\
January $\times$ July & $\mathrm{p}<0.050$ \\
February $\times$ June & $\mathrm{p}<0.050$ \\
February $\times$ July & $\mathrm{p}<0.050$ \\
\hline
\end{tabular}

After the annual rings were validated, three readings were performed for each otolith, giving mean values of the Coefficient of Variation (CV) of $2.6 \%$ and of the Average Percentage Error (APE) of $1.99 \%$. These values indicate that the accretion structure had a suitable reading quality. To minimize the error of the results, the otoliths that showed disagreement between readings were discarded, i.e., 80 otoliths of the total of 571 . This represented a legibility of $86 \%$ for the sagittae otoliths of C. edentulus.

For the visualization of the results for the age of the population, the age/length key shows the absolute values found between August 2001 and July 2003 (Tab. II) and the percentages of individuals sampled by age in each length class. The population structure in the study area covers an age range of 0 (first year of life or $<12$ months) to 4.0 years, with a predominance of individuals 1.0, 2.0 and 3.0 years old.

Table II. Age-length distribution obtained for C. edentulus in the Saco dos Limões bight (southern Brazil). Total length classes $(\mathrm{mm})$, age classes (year), total number ( $n$ ) and frequency (\%) by classes are indicated.

\begin{tabular}{|c|c|c|c|c|c|c|c|}
\hline \multirow{2}{*}{$\begin{array}{l}\text { Total length } \\
\text { class }(\mathrm{mm})\end{array}$} & \multicolumn{5}{|c|}{ Age class (year) } & \multirow{2}{*}{$\mathrm{n}$} & \multirow{2}{*}{$\%$} \\
\hline & 0 & 1.0 & 2.0 & 3.0 & 4.0 & & \\
\hline $36-40$ & 3 & & & & & 3 & 0.60 \\
\hline $41-45$ & 1 & & & & & 1 & 0.20 \\
\hline $46-50$ & 1 & & & & & 1 & 0.20 \\
\hline $51-55$ & 3 & & & & & 3 & 0.60 \\
\hline $56-60$ & 7 & & & & & 7 & 1.42 \\
\hline $61-65$ & 8 & & & & & 8 & 1.62 \\
\hline $66-70$ & 3 & & & & & 3 & 0.60 \\
\hline $71-75$ & 2 & & & & & 2 & 0.40 \\
\hline $76-80$ & 2 & & & & & 2 & 0.40 \\
\hline $81-85$ & 1 & 3 & & & & 4 & 0.81 \\
\hline $86-90$ & & 9 & & & & 9 & 1.83 \\
\hline $91-95$ & & 11 & & & & 11 & 2.24 \\
\hline $96-100$ & & 14 & & & & 14 & 2.85 \\
\hline $101-105$ & & 26 & 5 & & & 31 & 6.31 \\
\hline $106-110$ & & 26 & 6 & & & 32 & 6.51 \\
\hline $111-115$ & & 17 & 6 & & & 23 & 4.68 \\
\hline $116-120$ & & 6 & 15 & & & 21 & 4.27 \\
\hline $121-125$ & & 7 & 31 & 1 & & 39 & 7.94 \\
\hline $126-130$ & & & 29 & 8 & & 37 & 7.53 \\
\hline $131-135$ & & & 36 & 6 & & 42 & 8.55 \\
\hline $136-140$ & & & 30 & 20 & & 50 & 10.18 \\
\hline $141-145$ & & & 18 & 26 & & 44 & 8.96 \\
\hline $146-150$ & & & 7 & 32 & & 39 & 7.94 \\
\hline $151-155$ & & & 4 & 21 & 4 & 29 & 5.90 \\
\hline $156-160$ & & & & 19 & 3 & 22 & 4.48 \\
\hline $161-165$ & & & & 7 & 4 & 11 & 2.24 \\
\hline $166-170$ & & & & 2 & 1 & 3 & 0.60 \\
\hline $\mathrm{n}$ & 31 & 119 & 187 & 142 & 12 & 491 & 100 \\
\hline$\%$ & 6.31 & 24.24 & 38.08 & 28.92 & 2.44 & & \\
\hline Mean (n) & 3.1 & 13.2 & 17.0 & 14.2 & 3.0 & & \\
\hline$S d(n)$ & 2.5 & 8.4 & 12.4 & 10.7 & 1.4 & & \\
\hline
\end{tabular}


The von Bertalanffy growth curve was constructed for $C$. edentulus (Fig. 6), represented by the equation $\mathrm{L}_{\mathrm{t}}=156.70$ ( $1-$ $\left.\mathrm{e}^{-1.05(\mathrm{t}-0.002)}\right)$, involving the ages determined by the readings and the lengths estimated by iteration (Tab. III and IV). Based on literature data for the species in this area (SouZA-ConCEIÇ̃̃o et al. 2005), which show a length at first maturation of 112 and $118 \mathrm{~mm}$ for males and females, respectively, the age at maturity according to von Bertalanffy equation was 1.19 year for females, and 1.12 year for males. The value for the sexes combined was equal to that of females.

Table III. Parameters estimated for the von Bertalanffy growth model $\left(\mathrm{L}_{\alpha^{\prime}}, \mathrm{k}\right.$ and $\left.\mathrm{t}_{0}\right)$ using iterative method for $\mathrm{C}$. edentulus in the Saco dos Limões bight (southern Brazil).

\begin{tabular}{cc}
\hline Growth Parameters & Value \\
\hline $\mathrm{L}_{\infty}$ & $156.7 \mathrm{~mm}$ \\
$\mathrm{k}$ & 1.05 year $^{-1}$ \\
$\mathrm{t}_{0}$ & 0.0029 year $^{2}$ \\
\hline
\end{tabular}

Table IV. Ages and respective values of lengths calculated from the growth equation obtained for C. edentulus in the Saco dos Limões bight (southern Brazil).

\begin{tabular}{cc}
\hline Age Class (year) & Length $(\mathrm{mm})$ \\
\hline 0 & 63.8 \\
1.0 & 101.8 \\
2.0 & 137.5 \\
3.0 & 150.0 \\
4.0 & 154.4 \\
\hline
\end{tabular}

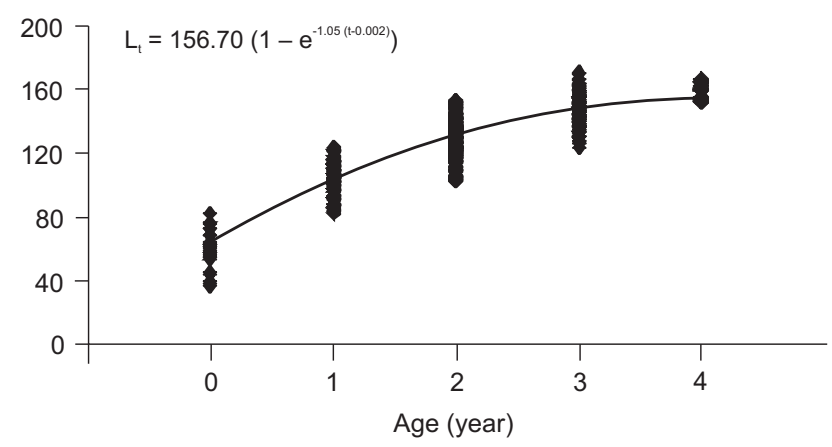

Figure 6. Von Bertalanffy growth curve obtained from the growth parameters determined by the iterative method for $C$. edentulus in the Saco dos Limões bight (southern Brazil).

\section{DISCUSSION}

HOWARD \& LANDA (1958) utilized temporal analyses of the modal progression of size groups and the Walford graph method, gonad analysis, maturation, as well as age-length relationships in order to estimate, among other parameters, the age at maturity of C. mysticetus. WHITEHEAD (1988) suggested that the biology of C. edentulus must be very similar to that of its congener, for which information is already available. This hypothesis was confirmed in the present study. The age at maturity obtained for $C$. edentulus is very similar to that of $C$. mysticetus (approximately one year of age in both species). According to He \& STEWART (2001), the age at maturity has broad implications for population studies and for community ecology, being considered as one of the major features in the life cycle of fish species.

Information about age provides the basis for calculating the patterns of growth and mortality, making it among the most influential biological variables (CAMPANA 2001). An important step in determining the age of a species is the validation of the results for the periodicity of the growth markers. The variation in deposition of microcrystals of $\mathrm{CaCO}_{3}$ (aragonite) and organic matter (otolin) on the surface of the otolith, as a function of the environmental and physiological factors affecting the fish, influences the transmission and reflection of light in the accretion structure. This condition forms optically different layers, establishing the alternating opaque and translucent zones (Vazzoler et al. 1982, CAMPANa 1985, SACCARDO et al. 1988, Morales-Nin 2000, Araújo et al. 2002b). Campana (2001) stated that in validating the marginal increments, one must use two independent methods, include juveniles up to the oldest possible individuals, preferably a species with rapid growth, samples from at least one year, and an analysis of at least 100 individuals. These assumptions were considered in the validation of the data obtained for $C$. edentulus, a species with rapid growth. It involved the use of recommended methods, including samples with juveniles to the largest adults, two years of data, and 571 individuals analyzed.

The utility of age and growth studies depends on the precision of the age-determination process (Joyeux et al. 2001). CAMPANa (2001) fully discussed the evaluation of precision among readings, and noted that a coefficient of variability (CV) of 5\% or less for shorter-lived fish, and the complexity of the readings, are important, and that the average percentage error (APE) generally has a slightly smaller value. In the present study, mean values for the coefficient of variability (CV) were $2.6 \%$, and for the average percentage error (APE) was $1.99 \%$. Even though our values were better-than-recommended, we opted to exclude, from the age analysis, all individuals for which variation occurred between readings, in order to minimize this source of error. Therefore, a total of 491 individuals were used in the age analysis.

The population structure found for C.edentulus indicates that the area is widely occupied by individuals of different ages, predominantly newly recruited adult fish in the age categories 2.0 and 3.0 years, and a minority in their fourth year of life. This configuration reinforces the importance of the area for the species during its entire life cycle. Fish of 1.0 year of age 
were caught, but in smaller quantities in relation to 2.0 years, supporting the hypothesis that the first are present in greater quantities in the Tavares River mangrove (Fig. 1). This hypothesis is related to the findings of Clezar (1998) and SouzaConCEIÇão et al. (2005), who described respectively an approximate age of 5 months $(34 \mathrm{~mm})$ for individuals caught in this ecosystem, and migration of larvae of the species toward that mangrove. In the Tagus estuary in Portugal, the engraulid Engraulis encrasicolus (Linnaeus, 1758), by means of larval-retention mechanisms, maintains the maximum density of its eggs and larvae in the middle and upper estuaries, respectively, and large larvae are always found in the upper estuary (Costa et al. 2002). This is a common pattern, because young fish often utilize estuaries as nursery grounds, benefiting from the availability of food and protection from predators (YANESArancibia 1986, McLusky 1994, Falcão et al. 2006, Costa \& SouzaCONCEIÇÃo 2009).

The population structure of a species can also be affected by intense fishing pressure. An example is a population of $C$. mysticetus composed on average of $90 \%$ of the individuals in the first year of life, $10 \%$ in the second, and less than $1 \%$ in the third (Howard \& LANDA 1958). In our study area, C. edentulus preserves a more-even distribution between the 1.0 and 3.0 year-age classes (Tab. II), which suggests a population still little affected by fishing.

The majority of clupeiforms have a short lifespan, recruit between 1.0 and 3.0 years of age, and rarely live more than 5-10 years, except for some herring stocks, especially Clupea harengus membras (Linnaeus, 1761) (Blaxter \& Hunter 1982). A prerequisite for measuring the relative abundance of the annual class available for fishing is the ability to distinguish the ages and to estimate the growth pattern of the fish (Howard \& Landa 1958). According to Blaxter \& Hunter (1982), early maturation implies that the asymptotic length $\left(\mathrm{L}_{\infty}\right)$ is reached rapidly and that older fish do not have very significant growth. In Santa Marta, Colombia, through analysis of the monthly length-frequency modes and the Ford-Walford graph method, Gallo-NieTo (1993a) determined an $\mathrm{L}_{\infty}$ of 178 $\mathrm{mm}$, $\mathrm{k}$ of 0.13 year $^{-1}$ and mean $\mathrm{t}_{0}$ of -1.17 year for C. edentulus. Using the same method, Clezar (1998) found an $\mathrm{L}_{\infty}$ of 165.3 $\mathrm{mm}$, $\mathrm{k}$ of 0.51 year $^{-1}$ and the parameter $\mathrm{t}_{0}$ stipulated as zero. For C. edentulus, the present study, using the iterative method, found an $\mathrm{L}_{\infty}$ of $156.7 \mathrm{~mm}$, $\mathrm{k}$ of 1.05 year $^{-1}$ and $\mathrm{t}_{0}$ of 0.002 year. Therefore, the growth rate of this species is very high when compared to other engraulids such as Anchovia clupeoides (Swainson, 1839) (GALlo-NiETo 1995) and Encrasicholina purpurea (Fowler, 1900) (Chiappa-Carrara et al. 1997), and close to that of E. encrasicolus (BELLido et al. 2000).

Some growth parameter determination methods can lead to higher values of $\mathrm{L}_{\infty}$ (Cergole 1995). Differences found between the growth parameters may be linked to the methods used. For instance, the graph methods of Ford-Walford and Gulland, in estimating the values of $\mathrm{L}_{\infty}, \mathrm{k}$ and $\mathrm{t}_{\mathrm{o}}$, overestimate the asymptotic size in relation to the iterative method for Opisthonema oglinum (Lesueur, 1818) (Feltrim \& Schwingel 2005). These differences were similar to those described for the growth parameters of $C$. edentulus between the graph method of FordWalford (GAllo-Nieto 1993a, Clezar 1998) and the iterative method used in the present study. Therefore, considering the already-described advantages of the iterative method, it is possible to state that the parameters determined in the present study express better the developmental characteristics of $C$. edentulus.

A thorough analysis of the ecology of C. edentulus is necessary in order to help us better understand the effects of certain actions that result in alterations in the habitat and population of this species. In order to explore fishery resources such as $C$. edentulus, it is necessary to know the population structure and its characteristics, as well as how the species interacts with the environment. In order to achieve that, we need to go beyond gathering information about age and growth, described in this study, and conduct further research on the spatio-temporal dynamics, and responses on environmental variables in the studied area. All the acquired knowledge will be useful in constructing a management plan for the species which apparently has been under exploited in the region - preventing its decline, and consequent economical and ecological loss.

\section{ACKNOWLEDGMENTS}

The authors thank the financial aid provided by the Departamento de Estradas de Rodagem, state of Santa Catarina (DER-SC). Logistical support was provided by CTTMar/UNIVALI, the Third Platoon of Environmental Police of Santa Catarina Aquatic Platoon (Florianópolis, SC) and by the Santa Catarina Yacht Club (Florianópolis, SC). The fisherman M. Antônio helped us collect the fish. The students of Oceanography and Biology (University of Vale do Itajaí) helped us during field work, J.A.A. Perez gave valuable suggestions and reviewed an earlier version of this text. We also thank the anonymous referees for their dedicated reading and excellent suggestions.

\section{LITERATURE CITED}

Araújo, F.G.; M.C.C. Azevedo; M.A. Silva; A.L.M. Pessanha; I.D. Gomes \& A.G. Cruz-FilHo. 2002a. Environmental influences on the demersal fish assemblages in the Sepetiba Bay, Brazil. Estuaries 25: 441-450.

Araújo, J.N.; A.S. Martins \& K.G. Costa. 2002b. Idades e crescimento da cioba, Ocyururs chrysurus, da costa central do Brasil. Revista Brasileira de Oceanografia 50: 47-57.

Bellido, J.M.; G.J. Pierce; J.L. Romero \& M. Míllan. 2000. Use of frequency analysis methods to estimate growth of anchovy (Engraulis encrasicolus L. 1758) in the Gulf of Cádiz (SW Spain). Fisheries Research 48: 107-115. 
Beverton, R.J.H. \& S.J. Holt. 1957. On the dynamics of exploited fish populations. London, U.K. Ministry of Agriculture, Fisheries and Food, Fishery Investigations Series II (19), 533p.

Blaxter, J.H.S. \& J.R. Hunter. 1982. The biology of the clupeoid fishes. Advances in Marine Biology 20: 1-223.

Boenlert, G.W. \& B.C. Mundy. 1988. Roles of behavioral and physical factors in larval and juvenile fish recruitment to estuarine nursery areas. American Fisheries Society Symposium 3: 51-67.

Caldwallader, P.L. 1978. Age, growth and condition of the common river galaxias, Galaxias vulgaris Stokell, in the Glentui River, Canterbury, New Zealand. Fisheries Research Bulletin 17: 9-35.

Campana, S.E. 1985. Microstructure of fish otoliths. Canadian Journal of Fisheries and Aquatic Science, Ottawa 42: 10141032.

Campana, S.E. 2001. Accuracy, precision and quality control in age determination, including a review of the use and abuse of age validation methods. Journal of Fish Biology 59: 197242.

Campana, S.E. \& C.M. Jones. 1992. Analysis of Otolith Microstructure Data. Canadian Special Publication of Fisheries and Aquatic Sciences 117: 73-100.

Cergole, M.C. 1995. Stock assessment of the Brazilian sardine, Sardinella brasiliensis, of the southeastern Coast of Brazil. Scientia Marina 59 (3-4): 597-610.

Chiappa-Carrara, X.; M. Gallardo-Cabello; M. Caso-Chávez \& A.L. IBÁÑEZ-Aguirre. 1997. Análisis del crecimiento de la anchoveta hawaiana Encrasicholina purpurea Fowler (Pisces: Engraulidae) en la Bahía de Kaneohe, Oahu, Hawai. Hidrobiológica 7: 1-8.

Clay, D. \& H. Clay. 1991. Determination of Age and Growth of White Hake (Urophycis tenuis Mitchill) from the Southern Gulf of St. Laurence, Canada (including techniques for commercial sampling). Canadian Technical Report of Fisheries and Aquatic Sciences 1828: 1-29.

ClezAr, L. 1998. Crescimento de Cetengraulis edentulus (Cuvier, 1828) (Clupeiformes - Engraulididae) no Manguezal do Itacorubi, SC, Brasil, p. 229-238. In: E.J. Soriano-Sierra \& B. Sierra de Ledo (Eds). Ecologia e gerenciamento do Manguezal do Itacorubí. Florianópolis, NEMAR/CCB/ UFSC, SDM/FEPEMA, 440p.

Clezar, L.; G. Costa-Ribeiro; M. Hostim-Silva \& B.S. Ledo. 1993. Abundância e distribuição de Cetengraulis edentulus (Cuvier, 1828) (Clupeiformes - Engraulidae) no Manguezal do Itacorubí, SC, Brasil. Arquivos de Biologia e Tecnologia 36 (3): 567-576.

Costa, M.J.; H.M. Cabral; P. Drake; A.N. Economou; C. FernandezDelgado; L. Gordo; J. Marchand \& R. Thiel. 2002. Recruitment and production of commercial species in estuaries, p. 54123. In: M. Elliott \& K.L. Hemingway (Eds). Fishes in estuaries. Oxford, Blackwell Science, XX+636p.
Costa, M.D.P. \& J.M. SouzA-Conceição. 2009. Composição e abundância de ovos e larvas de peixes na baía da Babitonga, Santa Catarina, Brasil. Pan-American Journal of Aquatic Science 4 (3): 372-382.

Costello, M.; M. Elliott \& R. Thiel. 2002. Endangered and rare species, p. 217-265. In: M. Elliott \& K.L. Hemingway (Eds). Fishes in estuaries. Oxford, Blackwell Science, XX+636p.

Da-Graça-Lopes, R.; E. Severino-Rodrigues; A. Puzzi; J.B. Pita; J.A.P. Coelho \& M.L. De-Freitas. 1993. Levantamento ictiofaunístico em um ponto fixo na Baía de Santos, estado de São Paulo, Brasil. Boletim do Instituto de Pesca 20: 7-20.

Elliott, M. \& K. L. Hemingway. 2002. Fishes in estuaries. Oxford, Blackwell Science, $\mathrm{XX}+636 \mathrm{p}$.

Falcão, M.G.; V. Sarpédonti; H.L. Spach; M.E.B. Otero; G.M.L.N. QueIroz \& C. SANTOS. 2006. A ictiofauna em planícies de maré das Baías das Laranjeiras e de Paranaguá, Paraná, Brasil. Revista Brasileira de Zoociências 8 (2): 125-138.

Feltrim, M.C. \& P.R. Schwingel. 2005. Opisthonema oglinum, p. 112-115. In: M.C. Cergole; A.O. Ávila-Da-Silva \& C.L.D.B. Rossi-Wongtschowski (Eds). Análise das principais pescarias comerciais da região Sudeste-Sul do Brasil: dinâmica populacional das espécies em explotação. São Paulo, Edusp, Série documentos REVIZEE: SCORE SUL, 176p.

Figueiredo, J.L. \& N.A. Menezes. 1978. Manual de peixes marinhos do sudeste do Brasil. II. Teleostei (1). São Paulo, Edusp, 110p.

Gallo-Nieto, J. 1993a. Aspectos reproductivos de la anchoveta rabo amarillo Cetengraulis edentulus (Cuvier, 1829) en la Cienaga Grande de Santa Marta (Magdalena - Colombia). Boletín Científico INPA 1: 24-42.

Gallo-Nieto, J. 1993b. Edad e crecimiento de la anchoveta-raboamarillo Cetengraulis edentulus (Pisces: Engraulidae) en la Cienaga Grande de Santa Marta (Colombia). Boletín Científico INPA 1: 61-76.

Gallo-Nieto, J. 1995. Edad e crecimiento de la anchoveta Anchovia clupeoides (PISCES: Engraulididae) en la Cienaga Grande de Santa Marta (Colombia). Boletín Científico INPA 3: 136-144.

García-Abad, M.C.; A. Yánez-Arancibia; P. SÁnchez-Gil \& M. TaíAGarcía. 1998. Distribución, abundancia y reproducción de Opisthonema oglinum (Pisces: Clupeidae) en la plataforma continental del sur del Golfo de México. Revista de Biología Tropical 46 (2): 257-266.

GULLAND, J.A. 1988. Fish population dynamics: the implications for management. New York, John Wiley \& Sons, XV+422p.

GulLAND, J.A. 1989. Fish stock assessment: a manual of basic methods. New York, John Wiley \& Sons, XII+223p.

He, J.X. \& D.J. Stewart. 2001. Age and size at first reproduction of fishes: predictive models based only on growth trajectories. Ecology 82 (3): 784-791.

Hilborn, R. \& C.J. Walters. 1992. Quantitative fisheries stock assessment: choice, dynamics \& uncertainty. New York, Chapman Hall, XV+570p. 
Howard, G.V. \& A. LANDA. 1958. A study of the age, growth, sexual maturity and spawning of the anchoveta (Cetengraulis mysticetus) in the Gulf of Panama. Bulletin Inter-American Tropical Tuna Commission 2 (9): 389-437.

Joyeux, J.C.; C. Aliaume \& A. Zerbi. 2001. An alternative to validation of otolith microincrementation. Journal of Fish Biology 58: 873-879.

KIMURA, D. 1980. Likelihood methods for the von Bertalanffy growth curve. Fishery Bulletin 77 (4): 765-766.

KING, M. 1996. Fisheries biology, assessment and management. Oxford, Fishing News Books, IX+341p.

Lowe-Mcconnell, R.H. 1999. Estudos ecológicos de comunidades de peixes tropicais. São Paulo, Edusp, 534p.

Maldonado, H.G. \& C.R. Remolina. 1978. Contribution to knowledge of the biology and fisheries of the colombian anchovy, Cetengraulis mysticetus (Günther). Memoirs Seminar on the South American Pacific Ocean 1: 272-318.

Martins, R.S. \& M. Haimovici. 2000. Determinação de idade, crescimento e longevidade da abrótea de profundidade, Urophycis cirrata, Goode \& Bean, 1896, (Teleostei: Phycidae) no extremo sul do Brasil. Atlântica 22: 57-70.

McLusky, D.S. 1994. The estuarine ecosystem. New York, Chapman \& Hall, VIII+215p.

Morales-Nin, B. 2000. Review of the growth regulation processes of otolith daily increment formation. Fisheries Research 46: 53-67.

Moyle, B.P. \& J.J. Cech Jr. 1996. Fishes. An introduction to ichthyology. New Jersey, Prentice Hall, XVI+590p.

Nelson, G. 1984. Identity of the anchovy Hildebrandichthys setiger with notes on relationships and biogeography of the genera Engraulis and Cetengraulis. Copeia 2: 422-427.

Pessanha, A.L.M.; F.G. Araújo; M.C.C. Azevedo \& I.D. Gomes. 2003. Diel and seasonal changes in the distribution of fish on a southeast Brazil sandy beach. Marine Biology 143: 1047-1055.

Rozas, L.P. \& T.J. Minello. 1997. Estimating densities of small fishes and decapod crustaceans in shallow estuarine habitats: a review of sampling design with focus on gear selection. Estuaries 20 (1): 199-213.

SaCcardo, S.A.; C.L.D.B. Rossi-Wongtschowski; M.C. Cergole \& M.M. Bittencourt. 1988. Age and growth of the southeastern Brazilian sardine, Sardinella brasiliensis, 1981-1983. Boletim do Instituto Oceanográfico 36 (1-2): 17-35.
Schettini, C.A.F.; J. Pereira Filho \& L. Spillere. 2000. Caracterização oceanográfica e biogeoquímica dos estuários dos rios Tavares e Defuntos, Reserva Extrativista de Pirajubaé, Florianópolis, SC. Notas Técnicas da Facimar 4: 11-28.

Sergipense, S. \& D.G. Pinto. 1995. Aspectos de ocorrência e distribuição espacial da ictiofauna da Lagoa de Itaipu, Niterói - Rio de Janeiro. Publicação Especial do Instituto Oceanográfico 11: 179-186.

Sergipense, S.; E.P. Caramaschi \& I. Sazima. 1999. Morfologia e hábitos alimentares de duas espécies de Engraulidae (Teleostei, Clupeiformes) na Baía de Sepetiba, Rio de Janeiro. Revista Brasileira de Oceanografia 47: 173-188.

Souza-Conceição, J. M.; M. Rodrigues-Ribeiro \& M.A. Castro-SiLVA. 2005. Dinâmica populacional, biologia reprodutiva e o ictioplâncton de Cetengraulis edentulus Cuvier (Pisces, Clupeiformes, Engraulidae) na enseada do Saco dos Limões, Florianópolis, Santa Catarina, Brasil. Revista Brasileira de Zoologia 22 (4): 953-961.

Sparre, P. \& S.C. Venema. 1997. Introdução a avaliação de mananciais de peixes tropicais. Parte 1: Manual. Roma, FAO, FAO Documento Técnico sobre as Pescas 306(1), 404p.

VANNUCI, M. 1998. The mangrove ecosystem: an overview of present knowledge. Revista Brasileira de Biologia 58 (1): 1-15.

Vazzoler, A.E.A.M; C.L.D.B. Rossi-Wongtschowski \& F.M.S. BRAGA. 1982. Estudos sobre estrutura, ciclo de vida e comportamento de Sardinella brasiliensis (Steindachner, 1879), na área entre $22^{\circ} \mathrm{S}$ e $28^{\circ} \mathrm{S}$, Brasil. 2. Determinação da idade individual e crescimento dos otólitos. Boletim do Instituto Oceanográfico 31 (2): 77-84.

Vieira, J.P. \& C. Scalabrin. 1991. Migração reprodutiva da "tainha" (Mugil platanus Günther, 1980) no sul do Brasil. Atlântica 13 (1): 131-141.

VON BERTALANFFY, L. 1938. A quantitative theory of organic growth (Inquiries on growth laws II). Human Biology 10: 181-213.

YaÑEZ-ArancíbIA, A. 1986. Ecología de la zona costera: análisis de siete tópicos. México, AGT, 200p.

WhiteheAd, P.J.P. 1988. Clupeoid of the world (Suborder Clupeoidei): An annotated and illustrated catalogue of the herrings, sardines, pilchards, sprats, shads, anchovies and wolf-herrings. Rome, FAO Fisheries Synopsis 125 (7), 579 p.

Submitted: 06.VIII.2010; Accepted: 02.I.2011.

Editorial responsibility: Cassiano Monteiro Neto 